\title{
Kütanöz Vaskülitler
}

Cutaneous Vasculitis

\section{Özet}

Vaskülit kan damar duvarında kanama ve/veya iskemik olaylara neden olan vasküler inflamasyon șeklinde tanımlanmaktadır. Vaskülitlerin en sık görülen klinik bulgusu palpabl purpura olmasına karşın hastalar ürtiker, infiltratif eritem, peteşi, purpura, purpurik papüller, hemorajik veziküller ve büller, nodüller, livedo retikülaris, derin ülserler ve dijital gangren gibi lezyonlarla da başvurabilirler. Vaskülitik hastalıklarda sınıflamalar önemlidir ve tutulan damar çapına göre yapılan sınıflama en yaygın kabul görendir. Bu derlemede kütanöz vaskülitlerin en sık görülen formları üzerinde durulmaktadır. (Türkderm 2010; 44: 50-60)

Anahtar Kelimeler: Kütanöz vaskülitler, vaskülitlerin deri bulguları, kütanöz vaskülitlerin tedavisi

\section{Summary}

Vasculitis is defined as inflammation directed at vessels, which compromises or destroys the vessel wall leading to haemorrhagic and/or ischaemic events. Although the most common clinical finding of vasculitis is palpable purpura, patients may also present with other lesions including urticaria, infiltrative erythema, petechiae, purpura, purpuric papules, haemorrhagic vesicles and bullae, nodules, livedo reticularis, deep ulcers and digital gangrene. Classification systems have been important in the study of vasculitic diseases, and the most widely accepted one is based on the size of the vessel involved. This article will focus on the most common forms of cutaneous vasculitis. (Turkderm 2010; 44: 50-60)

Key Words: Cutaneous vasculitis, cutaneous findings of vasculitis, treatment of cutaneous vasculitis

\section{Giriş}

Vaskülit kan damar duvarında kanama ve/veya iskemik olaylara neden olan vasküler inflamasyondur, vücudun herhangi bir organ sistemini etkileyebilir ve tutulan damarlarla ilişkili olarak bulgulara neden olur. Vaskülit etyolojisinde rol oynayan faktörler oldukça geniş bir spektrum içerisinde yer almalarına karşın, klinik ve histopatolojik bulguların etyolojiye spesifik değişiklikler göstermemesi vaskülitlerin sınıflandırılmasında zorluklara neden olmaktadı ${ }^{1,2}$. Vaskülitleri etyolojilerine, kinik bulgularına, tutulan damar çapına ya da etkilenen organ sistemine göre sınıflamak mümkündür, en yaygın kabul gören sınıfla- ma, 1994'te Chapel Hill Consensus Conference (CHCC)'ın tutulan damar çapına göre yaptığı sınıflamadır ${ }^{3}$. Bu sınıflama küçük, orta ve büyük damarları etkileyen vaskülitler şeklindedir (Tablo 1$)^{4-6}$. Vaskülitler arteryel ve/veya venöz sistemin küçük, orta ve büyük çaplı damarlarını etkileyebilirler. Süperfisyel ve orta dermiste yerleşen arteriyol, kapiller ve postkapiller venüller; küçük damarlar, derin dermis veya subkutan dokuda yerleşen küçük arter ve venler; orta çaplı damarlar, aort ve diğer ana arterler ise büyük çaplı damarlar olarak adlandırılırlar ${ }^{2,5,6}$. Deri lezyonları sıklıkla küçük ve orta çaplı damarların vaskülitiyle ortaya çıkar'. Esas olarak deri dışındaki organları etkileyen orta çaplı damar vaskülitlerine de deri bulguları değişik oranda eşlik eder ${ }^{2,5}$.

Yazıșma Adresi/Address for Correspondence: Dr. Nilsel Ilter, Gazi Üniversitesi Tıp Fakültesi, Dermatoloji Anabilim Dall, Ankara, Türkiye E-posta: nilsel@gazi.edu.tr Geliş Tarihi/Received: 27.05.2010 Kabul Tarihi/Accepted: 27.05.2010

Türkderm-Deri Hastalıkları ve Frengi Arşivi Dergisi, Galenos Yayınevi tarafından basılmıştır

Turkderm-Archives of the Turkish Dermatology and Venerology, published by Galenos Publishing. 
Vaskülit tanısında en önemli histolojik bulgular inflamatuvar hücre infiltratı ve vasküler hasar bulgularıdır. Vasküler hasar bulguları, endotelde ödem ve eritrosit ekstravazasyonu, endotel nekrozu ve/veya damar lümeninde ve duvarlarında fibrinoid materyal birikimi, damar duvarlarında inflamatuar hücre infiltrasyonu ve lökositoklazidir'. Vaskülitte damar yapısında belirgin bozulma olmalıdır. Belirgin damar hasarı yokluğunda ödem, eritrosit ekstravazasyonu, lökositoklazi, damar duvarlarında infiltrasyon ve tromboz gibi minimal vasküler hasarı gösteren bazı değişiklikler vaskülit olarak kabul edilmemektedir ${ }^{1,5}$. Primer vasküler hasar, vasküler hasardan kaynaklanan hastalığa, sekonder veya insidental vasküler hasar ise damar dışı bir hastalıktan kaynaklanan vasküler patolojiye işaret eder. Tek histolojik örnekte primer veya sekonder vasküler hasarı ayırt etmek genellikle mümkün değildir. Vaskülopati veya pseudovaskülit terimi ise vaskülit kriterlerine tam olarak uymamakla birlikte belirgin derece vasküler değişiklik olan durumları tanımlamak için kullanılır¹.

\section{Küçük Damar Vaskülitleri}

\section{Kütanöz Lökositoklastik Vaskülit}

Kütanöz lökositoklastik vaskülit derideki küçük kan damarlarını esas olarak da postkapiller venülleri etkiler. 1950'lerde Zeek küçük damar vaskülitlerini mikroskopik özelliklerine göre sınıflayarak, ilaca sekonder küçük damar vasküliti gelişen olgular için hipersensitivite vasküliti ismini kullanmıştır ${ }^{7,8}$. 1990 yılında Amerikan Romatoloji Koleji'nin klasifikasyon kriterlerinde de bu isim korunmuştur ${ }^{9} .1994$ yılında hazırlanan CHCC sınıflamasında kütanöz lökositoklastik anjiitis, küçük damar vaskülitleri içinde deriye sınırlı olan form şeklinde tanımlanmıştır³. Kütanöz küçük damar vasküliti, hipersensitivi- te anjiti, kütanöz nekrotizan vaskülit, kütanöz nekrotizan venülit aynı tablonun sinonimleridir ${ }^{2,5,10}$. Bazı yazarlar CHCC'e $^{\prime}$ sadık kalarak kütanöz lökositoklastik vaskülitin deriye sınırlı vaskülit olduğunu ${ }^{4,6}$, bazıları ise sistemik tutulumun az oranda ve hafif şiddette olabileceğini belirtmektedir 2,5,11. Bu nedenle de kütanöz lökositoklasitk vaskülitin deri dışındaki sistem tutulumlarının sınırları çok iyi tanımlanamamıştır ${ }^{4,6,10}$.

Sistemik küçük damar vaskülitlerinde dermal komponentin etkilenmesi de kütanöz lökositoklastik vaskülitle aynı histolojik bulgulara neden olduğundan, sistemik tutulumun her hastada dışlanması gereklidir 4,6,11,12. Kütanöz lökositoklastik vaskülitli olguların yaklaşık yarısında idiyopatik, diğer yarısında ilaçlar, kimyasallar, viral, bakteriyel ve fungal enfeksiyonlar, süt proteini veya gluten alerjileri, lenfoproliferatif bozukluklar, solid tümörler, konnektif doku hastalıkları, inflamatuvar barsak hastalıkları gibi kronik hastalıklarla ilişkilidir (Tablo 2) 2,10,13-15. Küçük damar vasküliti düşündüren tüm olgularda özellikle de sistemik bulguların eşlik etmediği deriye sınırlı vaskülit tablolarında ilaç etyolojisi mutlaka düşünülmelidir. İlaçlar vaskülitik deri lezyonlarının \%10'undan sorumludurlar. İlaçlarla tetiklenen vaskülit tipik olarak ilacın başlanmasından 7-21 gün sonra başlar ${ }^{6}$.

Kütanöz lökositoklastik vaskülit erken dönemde maküler daha sonra palpabl olan purpuralar, eritemli papüller, veziküller veya ürtikeryal lezyonlarla karakterizedir. Nadiren püstüller ve eritema multiforme benzeri lezyonlar görülebi$\operatorname{lir}^{2,16}$. Daha az sıklıkla olmakla birlikte kütanöz lökositoklastik vaskülitte alt bacakta endüre eritemli alanlar, yüzeyel ülserler, hemorajik büller bulunabilir ${ }^{12}$. Lezyonlar simetrik olarak alt ekstremite ve bilekler, staza yatkın diğer alanlar, travmadan etkilenen alanlar veya giysilerin bası yerlerini tutma eğilimindedir, bu bulgular hidrostatik basınç ve stazın pato-

Tablo 1. Vaskülitlerin damar çapına göre sınıflanması ${ }^{4,6}$

\begin{tabular}{|l|c|c|}
\hline Küçük damar vaskülitleri & Orta çaplı damar vaskülitleri & Büyük damar vaskülitleri \\
\hline Kütanöz lökositoklastik vaskülit & Poliarteritis nodoza & Takayasu arteriti \\
\hline Henoch schönlein purpura & Kawasaki hastalığı & Giant cell arteritis \\
\hline ANCA pozitif vaskülitler & - & - \\
\hline Wegener granülomatozis & - & - \\
\hline Churg strauss sendromu & - & - \\
\hline Mikroskopik polianjitis & - & - \\
\hline Kriyoglobulinemik vaskülit & - & - \\
\hline
\end{tabular}

Tablo 2. Kütanöz lökositoklastik vaskülitlerin etiyolojisi ${ }^{10}$

\begin{tabular}{|l|c|c|}
\hline Eşlik eden kronik hastalıklar & \multicolumn{1}{|c|}{ Predispozan olaylar } & Idiyopatik hastalıklar \\
\hline Romatoid artrit & Bakteriyel viral ve mikobakteriyel enfeksiyonlar & Henoch schönlein purpura \\
\hline Sjögren sendromu & Teropötik ve tanısal ilaçlar & Ürtikeryal vaskülit \\
\hline Sistemik lupus eritematozus & - & Eritema elevatum diutinum \\
\hline Hipergamaglobulinemik purpura & - & Nodüler vaskülit \\
\hline Paraneoplastik vaskülit & - & Livedoid vaskülit \\
\hline Kriyoglobulinemi & - & Eozinofilik vaskülit \\
\hline Ülseratif kolit & - & Genetik kompleman eksiklikleri \\
\hline Kistik fibroz & - & İdiyopatik \\
\hline Antifosfolipid antikor sendromları & - & \\
\hline
\end{tabular}


fizyolojideki etkisini yansıtmaktadır. Kıvrım bölgeleri etkilenmeyebilir. Bazı hastalarda deri lezyonları daha yaygındır ve mukozal yüzeylerde de lezyonlar ortaya çıkar. Lezyonlar genellikle asemptomatiktir ancak yanma, ağrı veya kaşıntı tariflenebilir ${ }^{5,15}$.

Kütanöz lökositoklastik vaskülit esas olarak deriyi etkiler ancak renal, kas iskelet sistemi ve gastrointestinal sistemde de tutulum olabilir. Başvuru anında sistemik bulgular olmayan olgularda hastalığın seyrinde sistemik tutulumun gelişme olasılığı düşüktür ${ }^{11}$. Olguların \%10'undan azında gastrointestinal sistem ve renal sistem hastalığı bulunur. Ateş, artralji, miyalji anoreksi, gastrointestinal sistem bulguları veya nörolojik semptomların olması sistemik hastalığa işaret eden bulgulardır ${ }^{15}$.

Kütanöz lökositoklastik vaskülitte primer olay damar duvarında immün kompleks oluşumudur. İmmün komplekslerin komplemanı aktive etmesi ve C3a ve C5a anafilotoksinlerinin oluşumu ile başlayan süreç nötrofil kemotaksisinin uyarılmaSı, vazoaktif aminlerin ve proinflamatuvar sitokinlerin salınması, endotel hücrelerin aktivasyonu, inflamatuvar hücrelerin degranülasyon ürünleriyle damar duvarında hasar oluşturmasıyla sonlanır. Bu olayların sonunda kütanöz küçük damar vaskülitlerinin karakteristik histolojik bulgusu olan fibrinoid nekroz ortaya çıkmaktadır (Tablo 3) $)^{1,2,15}$.

Klasik histolojik bulgular küçük damar duvarlarının nukleusları karyoreksise uğramış nötrofillerle infiltrasyonu ve hasarlanan damar duvarlarında fibrinoid nekrozdan oluşmaktadır². Kütanöz lökositoklastik vaskülitin seyri oldukça değişkendir ve sorumlu ajanın ya da faktörün belirlenmesi, sistemik tutulumun olup olması, altta yatan hastalığın bulunup bulunmaması gibi faktörlerden etkilenir ${ }^{11,16}$. Hastalığın deriye sınırlı olduğu veya tetikleyici faktörün tespit edildiği olgularda lezyonlar genellikle üç dört hafta içinde kendiliğinden iyileşirler, olguların yaklaşık \%10'unda ise hastalık rekürren bir seyir gösterir ${ }^{6}$. Bir çalışmada artralji, kriyoglobulineminin eşlik etmesi ve ateş olmaması hastalığın kronik seyriyle ilişkili bulunmuştur ${ }^{5,6}$. Lezyonların iyileşme bölgelerinde önce ekimozlar daha sonra da post inflamatuvar hiperpigmentasyon görülür ${ }^{12}$.

Kütanöz lökositoklastik vaskülit kendiliğinden iyileşme özelliğinde olduğu için bazı hastalarda tedavi gerekli olmayabilir. Vaskülite neden olan faktörlerin belirlenmesi ve eliminasyonu sıklıkla ek tedaviye gerek kalmadan lezyonların kaybolmasını sağlar. Kütanöz lökositoklastik vaskülitte lokal ve sistemik tedaviler kullanılabilir ${ }^{15}$. Lokal tedavi seçenekleri arasında kortikosteroidler, kalsinörin inhibitörleri, antibiyotikler yer alır. Nonsteroid antiinflamatuvar ilaçlar ve antihistaminik kombinasyonları semptomatik tedavide etkili seçeneklerdir. Kütanöz lökositoklastik vaskülit tedavisi konusunda randomize kontrollü çalışma sayısı azdır. Şiddetli ve yaygın kütanöz tutulumda en etkili tedavi seçeneği sistemik kortikosteroidlerdir. Kortikosteroidler 60-80mg/gün şeklinde başlanarak 3-6 hafta süreyle kullanılırlar, rebound gelişimini önlemek için dozun kademeli olarak azaltılması önerilmektedir. Kolşisinin (0,6 mgx2-3/gün) faydalı etkileri tedavinin ikinci haftasından itibaren görülebilir ${ }^{17}$. Dapson (50-200 mg/gün), pentoksifilin (400 mgx3/gün), azatiyoprin, (50-200 mg/gün), siklofosfamid ( $2 \mathrm{mg} / \mathrm{kg} / \mathrm{gün})$, metotreksat (10-25 mg/hafta), siklosporin (3-5 mg/kg/gün) diğer tedavi seçenekleridir ${ }^{5,6,15}$.

\section{Henoch-Schönlein Purpura}

Henoch-Schönlein Purpura (HSP) tüm vaskülitlerin \%10'unu oluşturur. Hastalık esas olarak çocuklarda görülen IgA vasküliti olup kütanöz lökositoklastik vaskülitin spesifik bir formu olarak kabul edilmektedir. Klasik semptom tetradı; palpabl purpura, artrit, gastrointestinal sistem tutulumu ve nefritten oluşmaktadır ${ }^{2,12}$. Sekiz yüz yirmi yedi hastanın değerlendirildiği bir çalışmada alt ekstremite ağırlıklı yerleşim gösteren purpura veya peteşiye ek olarak karın ağrısı, lökositoklastik vaskülit ve IgA birikimi gösteren histopatoloji, artrit veya artralji ve renal tutulumun olması HSP'yi çocukluk çağının diğer vaskülitlerinden \%100 sensitivite ve spesifite ile ayırabilmektedir ${ }^{18}$.

HSP çocuklarda en sık görülen vaskülit formudur, sıklıkla 8 yaşın altında ortaya çıkar, erişkinlerde daha az sıklıkta görülür. HSP sıklığı mevsimsel dağılım gösterir ve hastalığın insidansı kış aylarında pik yapar ${ }^{5}$. Diğer kütanöz küçük damar vaskülitlerinde olduğu gibi HSP patogenezinde de immün kompleksler rol oynar².

HSP genellikle bir üst solunum yolu enfeksiyonunu sıklıkla da streptokokal faranjiti izleyen 1-2 haftalık süreçte ortaya çı$k^{5}{ }^{5}$. HSP ile ilişkili olabilen diğer enfeksiyonlar varisella ve bartonella enfeksiyonlarıdır ${ }^{19}$. Hastalık genellikle purpuralarla eşzamanlı veya hemen önce ortaya çıkan bitkinlik, başağrısı, hafif ateş, karın ağrısı ve artraljiyle başlar ${ }^{16}$. Erken dönemde simetrik dağılımlı maküler eritem veya ürtikeryal papüller şeklindeki deri lezyonları ilerleyen dönemde değişik büyüklükte inflamatuvar purpurik maküller ve papüllere ilerlerler ${ }^{2,5}$. Ürtiker, vezikül, bül ve fokal nekroz da görülebilir $^{2}$. Lezyonların predileksiyon bölgeleri alt ekstremitelerin ekstensör yüzleri ve glutealardır. Orta çaplı damar tutulumuna işaret eden kütanöz bulgular ve lezyonların yüzü de tuta-

\section{Tablo 3. Kütanöz lökositoklastik vaskülitin patogenezi}

İmmün komplekslerin kompleman sistemini aktive etmesi ve C3a -C5a anafilotoksinlerinin oluşumu:

- Kemotaktik faktörlerin salınması $\rightarrow$ Nötrofil kemotaksisinin uyarılması

- Vazoaktif aminlerin (histamin...vb)salınması $\rightarrow$ Endotel hücre retraksiyonu

- Proinflamatuvar sitokinlerin (IL-1, TNF- $\alpha$...vb) salınmasıł Endotel hücrelerden adezyon moleküllerinin (E-ve P- selektin) ekspresyonu Endotel hücrelerde selektin ekspresyonunu uyaran endotel hücre retraksiyonu ile immünkompleks birikimi:

- Nötrofillerin immünkompleksleri parçalamak için lizozomal enzimler salgılaması

- Nötrofillerin aktive olarak reaktif oksijen türevlerini salgılaması

- Inflamasyon $\rightarrow$ Damar duvarında fibrinoid nekroz 
cak şekilde yaygın olması altta yatan IgA monoklonal gammopatisi açısından araştırmayı gerekli kılar ${ }^{2,5}$.

HSP'li hastaların \%50-70'inde gastrointestinal sistem tulumu olur ve en sık kolik tarzında karın ağrısı şeklinde belirti verir, kusma da eşlik edebilir. Gastrointestinal sistem tutulumunda kanlı diare ve melena olguların yaklaşık yarısında vardır, şiddetli gastrointestinal sistem hastalığında karın ağrısı akut abdomeni düşündürecek ölçüde şiddetli olabilir. Barsak tutulumu perforasyon ya da intusepsiyon şeklinde de olabiliris,18. Renal tutulum olguların \%20-100'ünde görülen, prognostik önemi nedeniyle en ciddi komplikasyondur. Renal hastalık hafif ve geçici olabileceği gibi olguların $\% 5^{\prime}$ inde renal yetmezliğe de neden olabilir ${ }^{16}$. Erişkinlerde glomerülonefrit daha sıktır ve daha şiddetli olma eğiliminde olup, son dönem renal yetmezlik olguların \% $13^{\prime}$ ünde gelişir ${ }^{5,20}$. Renal tutulum için risk faktörleri; erişkin dönemde başlangıç, bel üstü bölgelerde purpuranın bulunması, ateş ve eritrosit sedimentasyon hızının yüksekliğidir, ${ }^{5,21}$. Erişkin dönemde son dönem re-

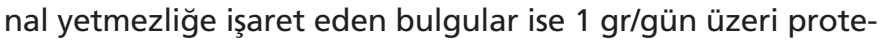
inüri, başlangıçta hipertansiyon, 30 yaş altında olmak, erkek cinsiyet ve renal biyopside intersitisyel firbrozis ve tubüler atrofi bulunmasıdır. Renal hasar belirtileri mezenşiyal ve endotel proliferasyon ile karakterizedir ve sıklıkla mikroskopik hematüri ve minimal proteinüri şeklinde ortaya çıkar,18,19.

Ayak bileği ve diz ekleminde artrit ve alt ekstremitelerde ödem şeklinde eklem bulguları \%60-90 oranında görülür. Erişkin hastalarda eklem tutulumu daha azdı2 $25,16,18$.

Histolojik olarak etkilenen damarlar venüller, kapillerler ve arteriyollerdir, bu damarlarda lökositoklastik vaskülit izlenmektedir. Direkt immünfloresan ile perivasküler granüler IgA, C3 ve fibrin birikimi görülür. Kütanöz vaskülitlerde diğer immünglobulinlerin yanı sıra değişik oranda IgA $\% 80$ oranında görülebildiğinden, HSP tanısı için baskın olan tipin IgA birikimi olması gerekmektedir ${ }^{2,421}$. Depolanan immünglobulin IgA1 subtipidir ${ }^{4,6}$.

HSP'nin prognozu iyidir. Başvuru esnasında üriner analizleri normal olanlarda kalııı renal hasar gelişmezken, bir tek tahlilde bozukluk olanların \%1,6'sında kalıcı renal hasar geliştiği görülmüştür. Bu nedenle ilk üriner tahlil normal olsa bile bu hastaların ilk altı aylık dönemde izlenmeleri önerilmektedir $^{13,21}$. HSP'li kadınlarda gebelik döneminde preeklempsi ve/veya proteinüri gelișme riski vardır,16,21.

Hastalık sıklıkla hafif şiddette ve kendini sınırlayan tiptedir4. Bu olgularda istirahat, analjezikler gibi destekleyici tedaviler yeterlidir'. HSP tedavisinin şekli büyük oranda eşlik eden renal hastalığın şiddetine bağlıdır ${ }^{6}$. Sistemik kortikosteroidler doku ödemini azaltarak, artrite ve gastrointestinal sistem bulgularına faydalı olabilirler, bununla birlikte, deri ve renal hastalıkta lezyonların süresini ve relaps oranını etkilemedikleri düşünülmektedir ${ }^{5,20,22}$. Erişkin dönemde deri, gastrointestinal sistem ve eklem hastalığının tedavisinde dapsonun faydalı olduğu bildirilmiştir. Şiddetli deri tutulumunda dapsonun çocuklarda da kullanılabileceği belirtilmektedir ${ }^{23}$. Şiddetli HSP glomerülonefritinin tedavisi ve bu tedavinin hastalığı seyrine etkisi konusu tartışmalı olmakla birlikte genel yaklaşım kortikosteroidlere ek olarak azatiyoprin ve siklofosfamid gibi immünsüpresanların kullanılmasıdır ${ }^{6}$. Nefritli hastalarda nonsteroid antiinflamatuvar ilaçlardan kaçınılmaIıdır ${ }^{5}$. Şiddetli olgularda önerilen diğer tedavi seçenekleri arasında plazmaferez, aminokaproik asit ve intravenöz immünglobulin (IVIG) vardır².

İnantil Akut Hemorajik Ödem

Infantil akut hemorajik ödem iki yaş altındaki çocuklarda görülen kütanöz küçük damar vaskülitlerinin nadir bir formudur. HSP'nin benign bir formu olarak da kabul edilen hastalığın klinik bulguları ve seyrindeki farklılıklar ayrı bir klinik antite olduğu düşündürmektedir. Hastalığın etiyolojisi bilinmemekle birlikte olguların \%75'i önceden geçirilmiş enfeksiyon, ilaçlar veya immünizasyon ile ilişkili bulunmuştur. En sık ilişkili olan enfeksiyon ajanları stafilokok, streptokok ve adenovirüslerdir. Penisilin, trimetoprim sülfometaksozol ve nonsteroid antiinflamatuvar gibi çeşitli ilaçların da hastalığı tetiklediği bildirilmiştir².

Kütanöz lezyonlar özellikle yüz ve distal ekstremitelerde yerleşim gösteren değişik derecede hemorajik, peteşiyal veya purpurik plaklar şeklindedir. Ağrılı olan lezyonlar, ödemin belirginleşmesiyle hedef benzeri bir görünüm alırlar. Lezyonlar tipik olarak proksimale yayılarak gövde ve genital bölgeyi, özellikle skrotumu tutarlar. Periferal veya fasiyal ödem görülebilir. Birçok hastada ateş mevcuttur fakat hastalar non-toksik görünümdedir, mukozal ve visseral tutulum nadirdir. Hastalık benign bir seyir gösterir ve 1-3 haftada spontan tam iyileşme görülür. Relaps beklenen bir bulgu değildir. Rutin laboratuar testleri nonspesifiktir ve tanı klinikopatolojik korelasyonla konulmaktadır2,10,16.

\section{Ürtikeryal Vaskülit}

Ürtikeryal vaskülit, klinik olarak ürtikeryal lezyonlar, histopatolojik olarak lökositoklastik vaskülit özellikleri gösteren kronik seyirli klinikopatolojik bir antitedir ${ }^{2,15}$

Ürtikeryal lezyonları olan hastaların yaklaşık \%5-10'unda ürtikeryal vaskülit vardır ${ }^{2,15}$. Ürtikeryal vaskülitlerin tanımlanmasından sonra i. Bazı hastaların normokomplementemik olduğu ii. Ürtikeryal vaskülitlerin beşte birinde solunum sistemi hastalığı geliştiği iii. Kollajen vasküler hastalıklarda ürtiker olduğunda bunun mutlaka ürtikeryal vaskülit şeklinde olduğu ve sistemik hastalığın seyri ile paralel bir seyir gösterdiği iv. Ürtikeryal vaskülitin hepatit ve paraproteinemilerle ilișkili veya paraneoplastik vaskülit şeklinde olabileceği v. Hastaların hemen tamamının uzun seyirli kronik ürtiker bulunduğu anlaşılmıştır.16 Hastalığın kompleman düzeyi ile belirlenen iki varyantı bulunur. Ürtikeryal vaskülit olgularının \%70-80'i normo, \%20-30'u ise hipokomplementemiktir $^{2,15}$. Normokomplementemik ürtikeryal vaskülit tanısı için hem atak sırasında hem de atak sonrası dönemde en az iki-üç kez kompleman (C3, C4, CH450) düzeylerine bakılma-

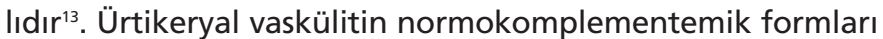
sıklıkla idiyopatiktir. Çok az bir kısmı ise monoklonal gamopatilerle ilişkilidir ${ }^{16}$.

Ürtikeryal vaskülit SLE (\%20) ve Sjögren sendromu (\%32) gibi otoimmün konnektif doku hastalıkları, IgM veya IgG monoklonal gamopatileri, kolon kanseri gibi neoplastik hastalıklar, hepatit B virüs (HBV), HCV ve Ebstein Barr virüs enfeksiyonları, potasyum iyodür, fluoksetin ve nonsteroid antiinflamatuvar ilaçlar ve serum hastalığıyla ilişkili olabilir2,15. 
Ürtikeryal vaskülitin patogenezi lökositoklastik vaskülite benzer. Hastalığın tip 3 hipersensitivite reaksiyonu ile geliştiği düşünülmektedir. Olguların $\% 75^{\prime}$ inde dolaşımda immün kompleksler belirlenmektedir ${ }^{15}$.

Ürtikeryal vaskülit lezyonları ürtikerden, plakların 24 saatten uzun süre devam etmesi ancak sıklıkla 72 saatten önce sonlanması, kaşıntıdan ziyade yanma ve ağrının eşlik etmesi, postinflamatuar hiperpigmentasyonla gerilemesi ve renginin viyole olması gibi özelliklerle ayrılır. Lezyonların merkezinde purpurik odaklar bulunabilir. Lezyonlar akral bölgelerden çok gövde ve proksimal ekstremitelerde yerleşirler ${ }^{5,12,13,15,2,2,24}$.

Kompleman düzeyleri normal olan hastalarda hastalık deride sınırlı olma eğilimindedir. Hipokomplementemik formda ateş, malazi, myalji, lenfadenopati, hepatosplenomegali, anjiyoödem, karın ağrısı, bulantı veya diare gibi gastrointestinal sistem semptomları, laringeal ödem, dispne, kronik obstriktif akciğer hastalığı gibi solunum sistemi semptomları, konjunktivit, episklerit veya üveit gibi oküler semptomlar olabilir ${ }^{215}$. Ürtikeryal vaskülitli olgularda renal tutulum sık değildir ${ }^{16}$. Oküler bulgular, anjiyoödem ve pulmoner bulgular ürtikeryal vaskülite işaret etseler de hastaların SLE'den ayrımı için otoantikorlar, lupus band testi gibi tetkiklerle değerlendirilmeleri gerekmektedir ${ }^{2,15}$.

Hipokomplementemik ürtikeryal vaskülit sendromu ise altı aydan uzun süre hipokomplementemi görülen ürtikeryal vaskülit ve eşlik eden sistemik bulgular olan olguları tanımlar. Nadir görülen bu tabloda hastalarda SLE'dekine benzer şekilde plörit ve glomerülonefrit vardır. Bu olgularda ürtikeryal vaskülit tanısının konulabilmesi için anti-C1q presipitinlerin olması gerekir, buna ilaveten C3 ve C4, aktif dönemde C1q düşüktür2,5,13,15. Ürtikeryal vaskülitin diğer laboratuar bulguları arasında eritrosit sedimentasyon hızı yüksekliği (\%28), hipokomplementemi (\%18), düşük titrede ANA pozitifliği (\%30-50) ve hematüri (\%29) bulunur ${ }^{5}$.

Histolojik olarak lökositoklastik vaskülit özellikleri vardır, normokomplementemik formda eozinofiller, hipokomplementemik formda yoğun interstisyel nötrofiller izlenir ${ }^{15}$. Ek olarak direkt immünfloresanda dermoepidermal bileşkede ve kan damarlarının çevresinde $\% 80$ olguda immünglobulin, fibrin ve kompleman bulunmaktadır ${ }^{13}$.

Ürtikeryal vaskülit tedavisi deri lezyonlarının yoğunluğuna ve eşlik eden sistemik bulgulara göre planlanır. Deriye sınırlı olan normokomplementemik hastalarda antihistaminikler ve/veya kortikosteroidler kısa süreli kullanılabilir. Diğer ajanlar dapson, kolşisin, hidroksiklorokin ve pentoksifilindir. Hipokomplementemik ürtikeryal vaskülit sendromunda ise tedaviye sistemik kortikosteroidlerle başlanılır. Şiddetli olgularda mikofenolat mofetil, ritüksimab, siklosporin, IVIG ve siklofosfamid kullanılabilir'13,17.

\section{Eritema Elevatum Diutinum}

Eritema elevatum diutinum (EED) ekstensör bölgelerde yerleşen kırmızı-mor papül, plak ve nodüllere karakterize nadir görülen kronik bir dermatozdur. Kütanöz vaskülitler için referans merkezlerden birinde 60 yıllık bir dönemde sadece 13 vakanın görüldüğü bildirilmiştir ${ }^{25}$. Hastalık her yaşta ortaya çıkabilmekle birlikte, orta yaşta veya daha ileri yaşlarda da- ha sıktır. Cinsiyetler arasında ve farklı ırklarda sıklık bakımından fark bulunmamaktadır,25-27.

EED etyolojisi kesin olarak bilinmemektedir ancak enfeksiyonlar, inflamatuar bağırsak hastalıkları, tekrarlayan polikondrit, SLE, romatoid artrit, plazma hücre diskrazileri, myelodisplazi, myeloproliferatif hastalıklar ve prostat kanseriyle ilişkili bulunmuştur. Olguların çoğunda EED hematolojik hastalıklardan daha önce ortaya çıkmaktadır. EED ile en sık ilişkili enfeksiyonlar beta hemolitik streptokoklar, HBV ve HIV enfeksiyonlarıdır'2,25.

EED'nin tekrarlayan immün kompleks depolanmalarıyla seyreden immün kompleks hastalığı olduğu kabul edilmektedir. Diğer küçük damar vaskülitlerinde olduğu gibi immün kompleks birikimi kompleman aktivasyonu, nötrofilik infiltrasyon ve lizozimler, kollagenaz gibi enzimlerin salınmasına neden olan süreç hastalığın geç evrelerinde dermal küçük damarların etrafında fibrin birikimiyle sonuçlanmaktadır ${ }^{2}$.

EED'nin tipik lezyonları el sırtı ve eklem ekstansör yüzlerinde yerleşen, simetrik dağılımlı, mor, kırmızı-kahverengi veya sarımsı papül, plak veya nodüllerdir. EED lezyonları kemik çıkıntılarının üzerindeki deride yerleşme eğilimindedir; el sırtı, diz-dirsek ekstensör yüzleri, el-ayak bileği çevresi, glutealarda da yerleşebilirler. Mukozalar ve gövde genellikle korunmuştur. Lezyonlar başlangıçta ödemli ve dolayısıyla da palpasyonla yumuşaktır, zamanla fibrozise bağlı olarak sertleşirler. Genellikle asemptomatik olan lezyonlarda ağrı ya da yanma tariflenebilir ${ }^{2,25}$. Bazı hastalarda görülen artraji dışında sistemik bulgu beklenmemektedir ${ }^{2,16}$

Hastalık kronik bir seyir gösterir, bununla birlikte olguların büyük çoğunluğunda 5-10 yıl süren kronik seyirden sonra hastalık spontan olarak geriler. Gerçekte mortalite yüksek değildir ancak belirgin morbidite vardır ${ }^{2,25-27}$.

Histopatolojik olarak EED erken lezyonlarında üst ve orta dermiste kama şekilli polimorf nüveli lökosit infiltrat ve lökositoklastik vaskülit değişiklikleri görülür. Papiller ve perifolliküler adventitisyel dermis tutulumu daha matür lezyonlarda izlenir. Erken dönemde klinik olarak psödovezikülasyonun görüldüğü tablolarda papillalarda ödem çok belirgindir. İlerleyen dönemde granülasyon dokusu ve nötrofillerin predominant olduğu mikst hücre infiltratı ve perivasküler, konsantrik veya storiform fibrozis görülür. Geç evrelerde kapiller duvarlarında fibrinoid nekroz veya fibrozis, iyi sınırlı dermal fibrozis nodülleri ve kolesterol depoları, skarlarda olduğu gibi vertikal kapillerler görülebiliri, ${ }^{1,26,27}$. Geç dönemlerde granülasyon yanıtıyla ilişkili olarak ortaya çıkan fibrozisin kronik dermal hasardan kaynaklandığı düşünülmektedir. Fibrozisin olduğu durumlarda vaskülitin tespit edilmesi için seri kesitlere ihtiyaç vardır ${ }^{2,26,27}$.

EED klinikopatolojik bir reaksiyon paternidir. EED tanısında tipik klinik bulgular ve histopatolojik bulgular birlikte değerlendirilmelidir. Hastalarda hematolojik malinitelerle ilişki araştırılmalı ve serum protein elektroforezi yapılmalıdır ${ }^{27}$.

EED, kronik ve rekkürren seyir göstermesi ve kronik dönemde fibrotik değişiklikler gelişebilmesi nedeniyle tedavisi zor bir hastalıktır. EED lezyonları diğer vaskülit tablolarında olduğu gibi eşlik eden ya da altta yatan patolojinin tedavisiyle geriler. Dapson EED'de dramatik düzelme sağlar ancak ilaç bıra- 
kılınca relaps olması dapsonun bu hastalıkta asıl olarak baskılama yaptığı ama şifa sağlayamadığını düşündürmektedir. Hastalığın geç dönemleri fibrotik değişiklikler nedeniyle dapsondan faydalanmamaktadır². Diğer tedavi seçenekleri arasında potent topikal, intralezyonel veya oral kortikosteroidler, nonsteroid antiinflamatuvar ilaçlar, niasinamid, tetrasiklinler, klorokin, kolşisin ve plazmaferez vardır ${ }^{2,27}$. HIV (+) hastalarda antiretroviral tedavi dapsona göre daha etkilidir ${ }^{27}$.

\section{Kriyoglobulinemik Vaskülit}

Kriyoglobulin soğukta presipite olan monoklonal veya poliklonal immünoglobulindir. Üç subtipi vardır. Tip 1; monoklonal IgM'dir ve her zaman hematolojik bir maliniteye eşlik eder. Tip 2; IgG'ye karşı gelişmiş monoklonal IgM'dir. Tip 3 ise IgG'ye karşı gelişmiş poliklonal IgG'dir. Tip 2 ve 3 mikst kriyoglobulinler olarak adlandırılırlar. Tip 1 kriyoglobulinemide, kriyoglobulinlerin damarı tıkaması nedeniyle iskemik vaskülopati izlenirken, mikst kriyoglobulinemide IgM-lgG komplekslerinin damar duvarında birikmesiyle tetiklenen inflamasyon sonucu sistemik vaskülit tablosu ortaya çıkar. Dolaşımda kriyoglobulinleri bulunan olguların \%15'inde kriyoglobulinemik vaskülit gelişir ${ }^{5}$.

Hastalık sıklıkla 50 yaş üzerinde ortaya çıkar.6 Kriyoglobulinemik vaskülitin en önemli sebepleri enfeksiyonlar (\%70), otoimmün (\%24) ve lenfoproliferatif (\%6) hastalıklardır. Enfeksiyonlar içinde en sık HCV kriyoglobulinemiyle ilişkilidir ${ }^{5}$. Mikst kriyoglobulinemi sıklığı genel populasyondaki HCV enfeksiyonu sıklığıyla paraleldir ${ }^{4}$. HCV'li hastaların \%54'ünde kriyoglobulinemi, yaklaşık \%5'inde ise kriyoglobulinemik vaskülit gelişir ${ }^{5}$. HIV (+) hastaların yaklaşık dörtte birinde dolaşımda kriyoglobulinler vardır. Otoimmün konnektif doku hastalıklarından romatoid artrit $\% 46$, SLE \%25, Sjögren sendromu $\% 16$ ve sistemik skleroz $\% 12$ oranında mikst kriyoglobulinemiyle ilişkilidir ${ }^{5}$.

Kriyoglobulinemik vaskülit patogenezinde immün sistemin virüsle kronik uyarılmasının rolü olduğu düşünülmektedir. HCV ile enfekte B hücrelerde klonal proliferasyonun gelişmesi, kriyoglobulin özelliğindeki poliklonal ve monoklonal immünglobulinlerin üretiminin tetiklenmesi ve immün komplekslerin oluşması karakteristik bulgulara neden olmaktadır $\mathbf{r}^{4,21}$.

Kriyoglobulinemik vaskülit tipik olarak deri, kas iskelet sistemi, sinir sistemi ve böbrekleri etkiler. Hastalık genellikle kronik seyir gösterir. En sık klinik bulgular purpura, artralji, artrit ve güçsüzlüktür. Kriyoglobulinemik vaskülitte alt ekstremiteler ve karın alt kısmında palpabl purpura en sık görülen deri bulgusu iken ekimozlar ve dermal nodüller daha az, ürtiker, livedo retikülaris, nekroz, ülserasyon ve büller ise nadiren görülen bulgulardır. Kriyoglobulinemik vaskülopatinin aksine mikst kriyoglobulinemik vaskülitin deri bulgularının soğukla ilişkisi daha az belirgindir ve olguların en çok üçte birinde tanımlanır. Raynoud fenomeni olguların \%20-50'sinde gelişebilir. Vaskülitlere sıklıkla eşlik eden artrit ve artralji, mikst kriyoglobulinemik vaskülitli olguların \%70'inden fazlasında multipl eklem tutulumuyla karakterizedir. Sinir sistemi tutulumu olguların $\% 40$ 'ında görülür, periferik tiptir ve sensöryal kusura neden olur. Membranoproliferatif glomerulonefrit olguların dörtte birinde ortaya çıkar ve en önemli morbidite sebebidir. Yirmi bir yıl takip edilen hastalardan elde edilen sonuçlar, renal tutulumun kötü prognoza işaret ettiği şeklindedir. Bununla birlikte son dönem böbrek hastalığı sıklıkla görülmez. Kriyoglobulinemik vaskülitte görülen diğer ekstrakütanöz bulgular arasında olguların üçte birinde görülen gastrointestinal hastalıklar veya hepatit vardır ${ }^{2,5,6,13,20}$. Laboratuar değerlendirmesinde dolaşımda kriyoglobulinlerin tespit edilmesi, hipokomplementemi, romatoid faktör pozitifliği, HCV serolojisinin pozitifliği tanıya yardımcı olur. Bu hastalarda C4 tipik olarak düşük, C3 ise normal ya da normale yakın değerdedir. Karaciğer transaminazları yüksek olabilir. Serum protein elektrofrorezinde olguların \%15'inde monoklonal pik görülür. Bu hastalarda ANA pozitifliği olabilirken antinötrofil sitoplazmik antikorlar (ANCA) pozitifliği çok nadirdir. HCV'ye göre daha düşük oranda HBV seropozitifliği de olabilir, bu nedenle tüm hepatit belirteçleri ve HIV için serolojik testler de yapılmalıdır ${ }^{4-6}$.

Histolojik olarak papüler lezyonlarda lökositoklastik vaskülit, nekrotik veya ülsere lezyonlarda ise orta çaplı damar vasküliti görülür. Direkt immünfloresanda papiller dermiste vasküler paternde IgM ve C3'ten oluşan depozitler izlenir². Mikst kriyoglobulinemi sıklıkla HCV ile ilişkili olduğu için tedavi öncesi HCV durumu netleştirilmelidir. HCV seronegatif hastada az sayıda purpura ve artralji varlığında nonsteroid antiinflamatuvar ilaçlar faydalı olur. HCV seropozitif hastada ilk tedavi seçeneği interferon ve interferon ile ribavirin kombinasyonlarıdır. HCV ilişkili olanlarda vaskülitin tedaviden faydalanma oranı büyük oranda virolojik yanıtla ilişkilidir. Interferonla yapılan çalışmalarda deri, renal ve eklem bulgularında belirgin düzelme ve kriyoglobulin miktarında azalma dikkat çekmektedir. Bununla birlikte interferonun periferik nöropati üzerine olumsuz etkisi nedeniyle periferik nöropatisi olan hastalarda interferon kullanımından kaçınılmalıdır. İnterferonun HCV ilişkili olmayan kriyoglobulinemik vaskülitte de etkili olduğunu gösteren yayınlar vardır ve bu etki immünomodulatuvar etkinlik ile açıklanmaktadır. Kriyoglobulinemi konnektif doku hastalığı veya malinitelerle ilişkili ise tedavi öncelikle bu hastalığa yönelik olmalıdır. Kortikosteroidlerin düşük dozları deri ve eklem hastalığı olan hafif şiddetteki olgularda, yüksek dozları ise renal ve nörolojik hastalıkta kullanılır. Şiddetli organ tutulumlarında sitotoksik ajanlarla (siklofosfamid, metotreksat, azatiyoprin) birlikte sistemik kortikosteroidler veya plazmaferezin kortikosteroid ve sitotoksik ajanlarla kombinasyonu önerilmektedir. Diğer tedavi seçenekleri arasında IVIG ve rituksimab vardır $r^{5,6,20,25}$.

\section{Predominant Olarak Kücük ve Orta Çaplı Damar Vaskülitleri}

\section{ANCA-ïlişkili Vaskülitler}

ANCA vaskülitler için yeni bir sınıflamaya olanak tanıyan serolojik markerlardır ${ }^{1}$. ANCA'lar normal popülasyonda \%5'in altında görülürler ancak ANA'nın aksine yaşlılarda sık değildirler ${ }^{5}$. ANCA pozitifliği en iyi ELISA ve bunu takiben normal periferik kan nötrofillerinin indirek immünfloresanıyla gösterilir. İndirek immünfloresanda iki boyanma paterni 
görülebilir; sitoplazmik (c-ANCA) ve perinükleer ( $p-A N C A)$. c-ANCA'nın çoğu proteinaz 3'e, p-ANCA'nın çoğu da myeloperoksidaz antijenine spesifik otoantikorlardır'. c-ANCA, p-ANCA'ya göre daha spesifiktir ${ }^{5}$. Bu otoantikorlar klinik özelliklerle birlikte üç küçük damar vaskülitinin ayırıcı tanısında kullanılmaktadır, bunlar: c-ANCA ilişkili Wegener granülomatozisi, p-ANCA ile ilişkili Churg-Strauss sendromu (CSS), p- veya c-ANCA'yla ilişkili mikroskopik poliarterittir (MPA). Bu üç hastalıkta vasküler hasar immünglobulin birikimiyle ilişkili değildir ve bu yüzden de pauci-immün vaskülitler olarak adlandırılmaktadır'. Bu antikorların ikisi bir arada bulunmaz, böyle birliktelik görülmüşse ilaç ile tetiklenen vaskülit tablosu düşünülmelidir ${ }^{5}$. ANCA pozitif vaskülitlerde pulmoner hemoraji ve kresentik nekrotizan glomerülonefrite bir yatkınlık vardır, bu nedenle de pulmoner renal sendrom olarak adlandırılırlar. Bu hastalıklarda renal hastalık bulguları geliştikten sonra renal yetmezliğe geçiş süreci çok hızlı ilerler ${ }^{5}$. ANCA pozitif vaskülitlerde hastaların erken tanısı önemlidir ve erken dönemde agresif tedavi, her üç hastalıkta da farklı organ sistemlerinin şiddetli tutulumunu baskılamak için gereklidir ${ }^{6}$.

ANCA dolaşan nötrofilleri ve monositleri aktive ederek damarlara adezyon ve degranülasyonlarını uyarır. Bu hücrelerden salınan toksik metabolitler de vasküler hasarı arttırarak vaskülit gelişimine neden olurlar'1.

Mikroskopik Polianjit: Mikroskopik polianjit (MPA), CHCC sınıflamasında küçük ve orta çaplı damarları etkileyen ve glomerulonefrit ve pulmoner kapillaritin sık görüldüğü nekrotizan vaskülit olarak tanımlanmıştır². Klasik poliarteritis nodoza (PAN) orta çaplı damarların daha ileri evre hastalığıdır, bu yüzden iskemik glomerular lezyon sıktır fakat glomerulonefrit nadirdir. MPA, diğer yandan, sistemik küçük damar vaskülitidir ve primer olarak arteriyol ve kapillerleri etkiler, tipik olarak kresentik fokal nekrotizan glomerulonefrite neden olur. Böbrek, akciğer ve derideki küçük damarların tutulumu MPA'ya özel bir klinik kazandırır ve MPA'yı klasik PAN'dan ayırır'.

MPA'lı hastaların büyük çoğunluğu erkektir. Hastalık sıklıkla 50 yaş üzerinde ortaya çıkar'. MPA'lı hastaların çoğunda ilk olarak grip benzeri bulgular, artralji ve miyalji ortaya çıkar. Deri tutulumu klasik PAN'da nadir görülse de MPA'lı hastaların en az \%30-40'ında deri bulguları vardır ve en sık palpabl purpura şeklindedir. Diğer deri değişiklikleri arasında eritemli maküller, livedo retikülaris, splinter hemorajiler ve ülserasyonlar yer alır. Ağrılı eritematöz nodüller MPA'da oldukça nadirdirler ve daha sık olarak WG, CSS ve PAN'da görülürler ${ }^{1,5}$.

MPA pulmoner renal sendromun en sık görülen sebebidir, renal ve pulmoner hastalığa bağlı ciddi klinik komplikasyonlar gelişebilir. En sık görülen ekstrakütanöz bulgu, olguların \%90'nında gelişen mikrohematüri, proteinüri veya akut oligürik renal yetmezlikle ortaya çıkan renal hastalıktır. PAN'da renal enfarkt ve arteryel anevrizmalar izlenirken, MPA'da primer patoloji pauci-immün kresentik nekrotizan vaskülittir. MPA'lı hastalarda renal tutulum prognozu önemli ölçüde etkiler, en önemli sorunlardan biri tanının gecikmesidir. Renal yetmezlik gelişmeden tedavi başlanılmalıdı2,6. Granülomatöz doku reaksiyonu olmaksızın pulmoner tutulum has- taların yaklaşık 1/3'ünde görülür. Bu olgularda hayati tehdit eden komplikasyon pulmoner alveoler hemorajidir ${ }^{1,2,6}$.

Hastaların \%35'inden fazlasında primer olarak periferal nöropati veya mononöritis multipleks şeklinde olan nörolojik tutulum görülür ${ }^{1,2,6}$. Mononöritis multipleks küçük damar vaskülitlerinde en sık görülen nöral patolojidir. Küçük epinöral arter ve arteriyollerin inflamasyonu ile ortaya çıkar ve nöral iskemi meydana gelir. Hem duyusal hem de motor lifler etkilenir. Meningeal damarların etkilenmesi durumunda santral sinir sistemi bulguları ortaya çıkar ${ }^{6}$. Diğer organ sistemleri, gastrointestinal sistem, serozal ve artiküler yüzeyler de daha az oranda etkilenirler'.

MPA'lı hastaların \%90'nından fazlası ANCA pozitiftir, çoğunlukla da p-ANCA'dır. \%10'unda her iki antikor da bulunmayabilir ${ }^{6,19}$. PAN'dan farklı olarak HBV serolojisi negatiftir ${ }^{6}$.

MPA'nın histolojisinde primer olarak arteriyol, venül ve kapillerleri etkileyen lökositoklastik vaskülit izlenir. Klasik PAN'da tipik olan orta çaplı arterlerin nekrotizan vasküliti ve granülomatöz inflamasyon nadirdir ${ }^{1,6}$. Pulmoner alveolar kapillarit, dermal lökositoklastik vaskülit, glomerülonefrit ve küçük damar tutulumlarının olması hastalığın PAN'dan ayrılmasını sağlar 6 .

\section{MPA'yı PAN'dan Ayıran Özellikler ${ }^{1,2,4,5}$ :}

- MPA'da histolojik olarak küçük damarların tutulması söz konusu iken PAN'da orta çaplı damar tutulumu daha belirgindir

- MPA'da deri tutulumu daha sıktır

- MPA'da pulmoner hastalık pulmoner kapillarit şeklindedir ve pulmoner hastalık genel olarak PAN'dan daha sıktır

- MPA'da renal hastalık glomerülonefrit şeklindedir; PAN'da görülen hipertansiyon, renal enfarkt veya vasküler anevrizmalar MPA'da görülmez

- MPA'da relapslar daha sıktır

- MPA'nın HBV ile ilişkisi yoktur

- MPA, ANCA pozitif bir vaskülittir

MPA'li hastalarda kontrollü terapötik çalışmalar yapılmamıştır. MPA'da WG gibi agresif tedavi edilir bu nedenle de, iki hastalıktan birinden şüphelenildiğinde erken dönemde agresif tedavinin başlanması önerilmektedir. Renal, pulmoner, nörolojik tutulumu olan olgularda başlangıç tedavisi olarak kortikosteroidler (1 $\mathrm{mg} / \mathrm{kg} / \mathrm{gün}$ ) ve siklofosfamid (2 mg/kg/gün) birlikte 3-6 ay indüksiyon tedavisi olarak kullanıldıktan sonra yan etkileri daha az olan azatiyoprin, metotreksat gibi ajanlarla tedavinin devamı önerilmektedir. Mikofenolat mofetil veya IVIG'ın etkili olduğu bildirilmektedir ${ }^{13}$. Hastalık şiddetinden bağımsız olarak MPA'li hastalarda relaps oranı klasik PAN'a göre daha yüksektir ve \%38 kadardır. Relaps görülen hastalarda indüksiyon tedavisine alınan yanıt benzerdir ${ }^{2,6,13}$.

Wegener Granülomatozis: WG'nin klasik triadı; üst ve alt solunum yollarının granülomatöz inflamasyonu, sistemik nekrotizan küçük damar vasküliti ve pauci-immün glomerülonefrittir ${ }^{5}$. WG kadınları ve erkekleri eşit oranda etkiler ve başlangıç yaşı 45-65'tir ${ }^{2,5,13}$.

WG patofizyolojisinde genetik ve çevresel faktörlerin rol oynadığı düşünülmektedir ${ }^{2}$. WG'nin klinik bulguları hastalar arasında büyük farklılıklar gösterir, bazı hastalarda uzun dö- 
nem nonspesifik konstitütyonel semptomlar ve üst solunum yolları bulgusu ile sinsi bir seyir izlenirken, bazı hastalarda ani başlangıçlı şiddetli pulmoner ve renal hastalık görülür ${ }^{1}$. Mukokütanöz bulgular WG'li hastaların yaklaşık \%46-56'sında ortaya çıkar ve \%10'unda ilk bulgu olabilir. WG'de üç grup lezyon görülür: 1. Küçük damar nötrofilik vaskülitine bağlı palpabl purpura 2. Orta çaplı damar tutulumuyla ilişkili subkutan nodüller, ülserler ve dijital infarktlar. 3. Polimorfik lezyonlar, pyoderma gangrenozuma benzeyen ağrılı subkutan nodüller ve ülserler, papülonekrotik lezyonlar, vezikülobüllöz lezyonlar ve gingival hiperplazi'12. Palpabl purpura ve oral ülserler en sık görülen bulgulardır. Pyoderma gangrenozuma benzeyen ağrılı subkutan nodüller ve ülserler, papülonekrotik lezyonlar WG'de sıktır. Papülonekrotik lezyonlar genellikle ekstremitelerde ortaya çıkarlar ancak bu lezyonlar nonspesifik görünümde olduğu için sıklıkla WG tanısının konulmasını sağlayamazlar ${ }^{1,2,5}$.

WG'li hastaların \%85'inden fazlasında migratuar, poliartiküler artralji ile küçük ve büyük eklemleri tutan artrit görülür ${ }^{1}$. Üst veya alt solunum yollarının hastalığı, olguların \%6080 'ninde görülür. Nazal, sinüs, trakeal ve kulak tutulumu şeklindeki solunum yolları hastalığında lokal destriksiyon vardır ve rekürren epistaksis, mukozal ülserasyonlar, nazal septum perforasyonu, subglottik stenoz gibi komplikasyonlara neden olabilir ${ }^{2,13,19}$. Pulmoner hastalıkta tipik olarak dispne, öksürük, hemoptizi veya plörit gelişir ve akciğer grafisinde infiltrat, nodüller, kavite veya buzlu cam görünümü ortaya çıkar ${ }^{13}$.

Tanı anında hastaların \%20'sinde renal hastalık vardır, fakat hastalığın seyri boyunca olguların \%80'ninde glomerülonefrit gelişir. Renal hastalık asemptomatiktir ve idrar sedimentinde proteinüri, mikroskopik hematüri, dismorfik eritrositler görülür $r^{20}$. Oküler, nörolojik ve gastrointestinal sistem hastalığı daha az görülür².

Aktif WG'li hastalarda ven trombozu riski vardır, bununla ilişkili olarak da derin ven trombozu ve pulmoner emboli gelişebilmektedir ${ }^{13}$.

Laboratuar bulguları inflamatuvar prosesle uyumludur ve akut faz reaktanlarında artış (ESR,CRP), anemi ve lökositoz mevcuttur. Hastaların \%50'sinden fazlasında romatoid faktör pozitiftir. c-ANCA klasik veya şiddetli WG'li hastaların $\% 80$ 'inde, p-ANCA ise yaklaşık $\% 10^{\prime}$ unda görülür. ANCA pozitif olmayan hastalarda lokal hastalık olduğu kabul edilir ve prognoz daha iyidir ${ }^{5}$. C-ANCA düzeyleri yükseldikten altı ay sonra olguların \%50'sinde WG'nin relaps yaptığı görülür. Bu nedenle de ANCA'ların hastaların takibinde kullanılabileceği de belirtilmektedir ${ }^{5}$. Renal hastalıkta aktif idrar sedimentleri, proteinüri, hematüri ve eritrosit kümeleri izlenebilir².

WG'de kütanöz lezyonların \%25-50'sinde karakteristik histopatolojik bulgular mevcuttur. En sık görülen bulgular nekrotizan/lökositoklastik küçük damar vasküliti ve granülomatöz inflamasyondur. Histiyositlerle çevrili küçük doku nekroz odakları görülebilir. Bu hastalarda ortasında nötrofillerle karışık nekrobiyotik kollagen ve bazofilik fibriler debrisler (mavi palizatik granülom) içeren WG granülomlarına ek olarak CSS'yi düşündüren palizatik granülomlar görülebilir'.
WG'li hastalar tedavi edilmezse mortalite oranı yüksektir ${ }^{2}$. Streroidlerin kullanılması beş yıllık sağ kalım oranını $\% 10$ 'dan \%55'e, kortikosteroidlerin siklofosfamid gibi immünsüpresanlarla birlikte kullanılması ise oranı $\% 75^{\prime}$ e yükseltmiştir. Bununla birlikte hastalarda siklofosfamide bağlı yan etkiler ve tedavi kesildikten sonra relapsların sık olması nedeniyle yeni tedavi arayışlarına gidilmiştir ${ }^{5}$. Klasik WG'de standart tedavi sistemik kortikosteroidler ( $1 \mathrm{mg} / \mathrm{kg} / \mathrm{gün}$ ) ve oral siklofosfamid ( $2 \mathrm{mg} / \mathrm{kg} / \mathrm{gün}$ ) ile indüksiyon ve idame tedavisidir. Birçok çalışmada klasik WG indüksiyon veya idame tedavisinde siklofosfamide alternatif olarak azatiyoprin, metotreksat ve mikofenolat mofetilin etkinliği gösterilmiştir. Siklofosfamid kullanımının kontrendike olduğu durumlarda IVIG veya plazmaferez yararlı olabilir. WG'de en önemli sorunlardan biri relapslardır. Beş yıllık takiplerde olguların yarısında görülmektedir. Relapsların S.aureusun solunum yolları enfeksiyonları ve nazal taşıyıcılığıyla ilişkili olduğu düşünüldüğü için immünsupresif tedavi rejimine trimetoprim sülfometaksozolün eklenmesi önerilmektedir. WG tedavisinde infliksimab, etanercept, rituksimab gibi biyolojik ajanların etkinliği araştırılmaktadır²,

Churg-Strauss Sendromu: Churg-Strauss Sendromu (CSS), multipl organ sistemlerindeki küçük-orta çağlı damarları tutan nekrotizan granülomatöz vaskülit, astım ve eozinofili ile karakterizedir². Nadir görülür, CSS insidansı kadın ve erkeklerde benzerdir. Hastalık tipik olarak hayatın 3. veya 4. dekadında ortaya çıkar ${ }^{1,2}$.

Sık tutulan iç organlar pulmoner sistem, gastrointestinal sistem ve daha az sıklıkla periferik sinirler ve kalptir ${ }^{1}$. Hastalığın seyri birbirlerini takip etmesi gerekmeyen üç fazla karakterizedir: Birinci fazda allerjik rinit, nazal polipler ve astım gibi semptomlar bulunur ve yıllarca devam eder. Gençlerde görülen alerjik astımın aksine CSS'de astım ortalama 35 yaşında ortaya çıkar. WG'den farklı olarak üst solunum yollarının tutulumu destrüktif değildir. İkinci fazda eozinofilik pnömoni, gastroeneterit ve periferik eozinofili vardır, bu dönemde relapslarla giden bir seyir izlenir. Üçüncü fazda granülomatöz inflamasyonla birlikte sistemik vaskülit gelişmesi söz konusudur. Bu faza geçiş 30 yıl sürebilir ${ }^{5,19}$. Semptomların başlangıcı aşılanma, desensitizasyon, lökotrien inhibitörleri ve kortikosteroidlerin ani kesilmesi gibi çeşitli tetikleyici faktörlerle ilişkilidir ${ }^{5}$. Hastalığın patogenezinde nötrofillerin ANCA ilişkili aktivasyonunun yanı sıra TH2 lenfositlerin aktivasyonu ve takiben mast hücre ve eozinofil degranülasyonu ile hızlı bir şekilde ortaya çıkan hipersensitivite reaksiyonları ve sitotoksik reaksiyonların rol oynadığı düşünülmektedir². Kütanöz bulgular hastaların \%40-70'inde görülürler. Deri lezyonları en sık ekstremitelerde yerleşir, gövde tutulumu da olabilir. En sık görülen deri lezyonu palpabl purpura ve saçlı deride veya ekstremitelerde yerleşen subkutan nodüllerdir. Peteşiler, ekimozlar, hemorajik büller, ürtiker, livedo retikülaris, retiform purpura ve papülonekrotik lezyonlar da daha az sıklıkla görülen bulgulardır ${ }^{2,5}$.

Mononöritis multipleks şeklindeki nörolojik tutulum vaskülitler içinde en sık bu hastalıkta görülür ve hastaların \%70'inde ortaya çıkar. WG'nin aksine myokardın granülomatöz inf- 
lamasyonu sık görülür ve CSS'li koroner arteritle birlikte hastalarda başlıca ölüm nedenidir. Nekrotizan glomerülonefrit sıklığı diğer ANCA ilişkili vaskülitlere göre daha azdır. Kas iskelet, gastrointestinal ve oküler sistemler de etkilenebilir. ${ }^{2,5,6}$ Laboratuar bulguları WG'li hastalarınkiyle benzerdir, ek olarak periferal eozinofili (>109/L) ve IgE yüksekliği de mevcuttur. CSS'de ANCA \%60-70 oranında pozitiftir ve çoğunlukla da $\mathrm{p}-\mathrm{ANCA}^{\prime} \mathrm{d} ı \mathrm{r}^{5,13}$.

Histolojik özellikleri eozinofilik doku infiltratları, dermal eozinofili, ekstravasküler granülom formasyonu ve küçük-orta çaplı damarların nekrotizan vaskülitidir ${ }^{13}$. Bu granülom predominant olarak radiyal olarak dizilim gösteren histiyositler ve sıklıkla dejenere kollagen fibrillerin etrafında yerleşen multinükleer dev hücrelerden oluşur. Granülomların orta kısmında dejenere kollagen fibriller, çok sayıda eozinofil (kırmızı palizatik granülom) yer alır, bazı olgularda vasküliti yakalamak zordur ${ }^{12,13}$.

CSS'li olguların çoğunda oral kortikosteroidler etkilidir. Nöropati, kortikosteroide dirençli glomerulonefrit, miyokardiyal hastalık, şiddetli gastrointestinal iskemi veya santral sinir sistemi tutulumu olanlarda steroidle birlikte sitotoksik ajanlar kullanılmalıdır

\section{Orta Çaplı Damar Vaskülitleri}

\section{Poliarteritis Nodoza}

Poliarteritis nodoza (PAN), orta çaplı kan damarlarını tutan segmental nekrotizan vaskülitle karakterize multisistem vaskülittir. Erkeklerde kadınlardan daha sık görülür ve orta yaşı-yaşlı erişkinleri (40-60 yaş) etkiler. Kütanöz PAN benin ve kronik seyir gösteren deride sınırlı bir varyantıdır².

PAN bazı enfeksiyon ve inflamatuvar hastalıklarla ilişkilidir. Klasik PAN'lı hastaların yaklaşık \%7'sinde HBV'nin patogenezde rol oynadığı düşünülmektedir. PAN'la ilişkili olduğu düşünülen diğer ajanlar streptokoklar, parvovirüs B19 ve HIV gibi enfeksiyonlardır².

PAN'da görülen segmental inflamasyon ve nekroz nedeniyle damar duvarının çevre dokuya doğru erode olması psödoanevrizmalara, tromboz akut iskemi ve doku enfarktlarına, anevrizmaların rüptürü de hemorajiye neden olabilir. Etkilenen damarlar orta çaplı damarlar olduğu için hemoraji hayatı tehdit edecek şiddette olabilir. Dermal ve subdermal kütanöz arterit nedeniyle kütanöz eritemli nodüller, ülserler, epinöral arterlerin arteriti sonucu periferik nöropati, iskelet kaslarındaki arterit sonucu myalji ve kas enzimlerinde yükselme, parenkimdeki arterlerin etkilenmesi sonucu herhangi bir visseral organda ağrı ve disfonksiyon ortaya çıkar ${ }^{1,4}$. Klasik PAN düşündüren ekstrakütanöz hastalıkta, hastalar sıklıkla kilo kaybı ve ateş gibi konstitutyonel semptomlar ve multipl organ tutulumuyla başvururlar. Sık görülen klinik bulgular karın ağrısı, artralji, miyalji, mononöritis multipleks ve konjestif kalp yetmezliğidir ${ }^{1,2,4,5,13}$. PAN'da sadece büyük tek bir epizod olur ve remisyon sağlandıktan sonra rekürrens az görülür ${ }^{4}$. Renal tutulum hastaların yaklaşık \%75'inde mevcuttur ve en sık ölüm nedenidir'. Böbrek tutulumu interlober renal arterler seviyesinde ortaya çıkar ve bu da glomerulonefritle değil renovasküler hipertansiyon ve renal yetmezlikle sonuçlanır ${ }^{1,4,5,13}$. Koroner arter tutulumu nedeniyle myokardiyal enfarkt gelişebilir ancak nadirdir ${ }^{4}$. Erkek ve özellikle HBV enfeksiyonuyla ilişkili olan hastalarda orşit sık görülür ${ }^{5}$.

Klasik (sistemik) PAN'lı hastaların yaklaşık \%20-50'sinde kütanöz tutulum bulunur. Livedo retikülaris ve geniş zımba (punched out) ülserler sık, subkutan nodüller ve digital enfarktlar daha az görülürler. Bu nodüller yüzeyel arterleri izlerler ve sıklıkla diz, alt bacak ön yüzü ve ayak dorsumunda ortaya çıkarlar ${ }^{5}$.

Hastalığın deride sınırlı formu olan kütanöz PAN, PAN’lı olguların \%10'unda görülür. Hastalarda ateş, miyalji, artralji ve periferik nöropati gibi hafif sistemik semptomlar olabilir, ancak diğer sistemik bulgular yoktur. Kütanöz PAN çocuklarda en sık görülen PAN formudur. Kütanöz PAN'ı düşündüren deri bulguları hassas nodüller, livedo racemosa, ülserler, akral gangren, nöropatidir. En sık görülen deri lezyonları genellikle alt ekstremitelerde özellikle de malleol çevresinde ağrılı subkutan nodüllerdir. Ülsere olabilen bu nodüllere sıklıkla yıldızvari saçılım paterninde livedo retikülaris eşlik eder. Bu lezyonların iyileşmesiyle atrophie blanche gelişebilir. Dijital enfarktlar çocuklarda sıktır. Periferik nöropati olguların \%20'sinde bulunur. Bazı olgularda spontan remisyonlar izlenir ancak kütanöz PAN kronik ve relapslarla karakterize benin bir klinik seyir gösterir ${ }^{5,12,21}$.

Klasik PAN'ın karakteristik lezyonu orta ve küçük çaplı arterleri tutan panarterittir. Klasik PAN'da birçok visseral alandaki arterlerde karakteristik değişiklikler izlenir, etkilenen deride ise sadece küçük damar hastalığı görülür, arteryal tutulum tipik olarak fokaldir. Kütanöz küçük damarlarda genellikle nekrotizan lökositoklastik vaskülitle uyumlu değişiklikler izlenir. Klinik olarak kütanöz nodüller bulunuyorsa visseral lezyonlara benzer şekilde panarterit görülür. Klasik PAN'da erken lezyonlarda fibrinoid materyal birikimiyle birlikte arteriyal duvar dejenerasyonu görülür. Eksternal ve internal elastik laminada parsiyel-tam kat destrüksiyon mevcuttur. Arteriyal duvar çevresinde büyük ölçüde nötrofillerden oluşan infiltrat vardır. Geç evrelerde infiltratta lenfositler, histiyositler, plazma hücreleri bulunabilir, bu evrede intimal proliferasyon ve tromboz gelişir, bu da lümenin tam oklüzyonuna, iskemi ve ülserasyona yol açar ${ }^{1}$. Direkt immünfloresanda damar duvarlarında veya perivasküler bölgede C3, IgM ve fibrin birikimi izlenir².

Klasik PAN'da laboratuar bulguları lökositoz, eritrosit sedimentasyon hızında artış ve trombositoz gibi nonspesifik inflamasyon bulgularıdır. Mikroskopik hematüri görülebilir fakat glomerülonefrit bulgusu yoktur. ANCA negatiftir. HBV serolojisi pozitif olabilir ${ }^{4}$.

Klasik PAN tanısı için tutulan organdan (deri, kas, sinir, böbrek, testis) alınan doku biyopsisinde karakteristik bulguların gösterilmesi ya da geleneksel veya magnetik resonans anjiografiyle renal, çölyak ve/veya mezenterik mikroanevrizmaların saptanması gerekmektedir ${ }^{1,2}$.

PAN'da serum kreatininin 1,58 üzerinde olması, 1 g/gün'ün üzerinde proteinüri olması, gastrointestinal sistem bulguları, santral sinir sistemi bulguları ve kardiyomyopati mortalitenin yüksek olduğu durumlardır²1. Bu faktörler yoksa beş yıllık 
mortalite oranı \%12 iken, biri varsa $\% 25$, ikisi varsa $\% 46^{\prime}$ dır $^{4}$. İdiyopatik klasik PAN'lı hastalara sistemik kortikosteroidler (1 mg/kg/gün) ile altı ay süreyle tedavi önerilir, steroid dozunun azalmasını tolere edemeyen hastalarda sitotoksik bir ajan eklenebilir. Major iç organ tutulumu olan hastalarda bu tedavi rejimine 6-12 ay süreyle siklofosfamid eklenmelidir. HBV ilişkili PAN tedavisinde virüs eradikasyonu amacıyla IFN$2 \alpha$ ve lamivudin gibi antivirallerin birlikte kullanımı ve tedavi yanıtı arttırmak için plazma değişimi önerilmektedir ${ }^{2,13}$.

Kütanöz PAN'da nonsteroid antiinflamatuvar ilaçlar ve aspirin bazı olgularda faydalı olabilir ancak sıklıkla yüksek doz başlanarak kademeli olarak azaltılan sistemik kortikoseroidler gerekli olur. Streptokokla sık ilişki nedeniyle penisilin hem teropötik hem de profilaktik olarak kullanılmaktadır. IVIG, sulfapiridin, düşük doz metotreksat ve pentoksifilin etkili olduğu bildirilen diğer ajanlardır ${ }^{2,5}$.

\section{Vaskülitli Hastalara Tanısal Yaklaşım}

Deri bulguları vasküliti düşündüren hastalarda anamnez, hastanın sistemik hastalıkları, otoimmün kollajen doku hastalığı, malinite..vb, kullandığı ilaçlar, geçirdiği enfeksiyonlar, gıdalar, gıda boyaları, aşı veya kimyasal maruziyeti sorgulanarak detaylandırılmalıdır. Deri bulguları değerlendirilirken aynı zamanda ateş, kilo kaybı, artralji, artrit, karın ağrısı, diare, hematokezya, öksürük, hemoptizi, sinüzit, parestezi ve hematüriye yönelik sistem sorgusu vaskülitin deri dışındaki organları etkileyip etkilemediğini değerlendirmede yardımcı olur ${ }^{2,24}$. Bu hastalarda fizik muayene ve dermatolojik muayene etkilenen damar çapını tanımlamayı ve sistemik tutulumun belirlenmesini sağlar. Damar çaplarına göre vaskülitlerin deri bulguları Tablo 4'de gösterilmektedir ${ }^{12,14}$. Sistemik vaskülitten şüphelenilen her hastada baş-boyun, kardiyopulmoner, abdomen, kas iskelet sistemi ve nörolojik muayene yapılmalıdır². Yapılacak tahliller tutulan damar çapına, hastalığın seyrine ve klinik şiddete bağlıdır. Eğer akut başlangıçlı bir tabloda ülserler yoksa, sistemik bulgu yoksa, hastanın bir süre sonra tekrar görülmesi yeterli olabilir. Kronik, şiddetli hastalık veya sistemik tutulum bulguları varsa daha kapsamlı araştırma gereklidir ${ }^{21}$.

Kütanöz vaskülit ön tanısı bulunan erişkin olgularda histolojik değerlendirmenin değeri tartışmasız kabul edilir bununla birlikte çocuklarda daha konservatif bir yaklaşım da kabul görmektedir. Biyopsi vasküliti taklit eden durumların dışlanmasına da yardımcı olur. Konnektif doku hastalığı, romatoid artrit gibi hastalıklarda vaskülit şüphesi varsa kural olarak biyopsi almak gereklidir ${ }^{24}$.

Vaskülitlerin tanısında histopatolojik bulgular önemli olmakla birlikte vasküler hasarın dinamik natürü histopatolojik değerlendirmede zorluklara neden olmaktadır. Hasarlanan damarların görünümü ve baskın inflamatuvar hücre tipinin zaman içerisinde değişiklik göstermesi, vasküler hasar derecesinin lezyonun şiddetine göre farklılık göstermesi, aynı vaskülitik olayın farklı yaşlardaki lezyonlarında histolojik görünümün farklı olması nedeniyle hem biyopsi zamanı hem örneklem yapılacak lezyonun ve lezyondan alınacak örneğin yerinin seçimi aşamasında dermatologa önemli görev düşmektedir ${ }^{1,2,5}$. Orta çaplı damar vaskülitinde biyopsi ülser olmayan bölgelerden alınmalıdır, ülser kenarından veya livedo retikülaristen alınan biyopsilere göre nodüllerden alınan biyopsinin tanısal değeri daha yüksektir. Bu mümkün değilse, ülserin tabanında sıklıkla insidental vaskülit geliştiğinden, biyopsi aktif kenardan alınmalıdır. Livedo retikülaristen biyopsi alınması planlanıyorsa biyopsi merkezdeki beyaz alandan alınmalıdır²,12,21,24.

Küçük damar vaskülitlerinde en hassas, kırmızı veya purpurik olan deri lezyonundan subkutise uzanan derin bir biyopsisi tanı için en ideal olanıdır ${ }^{14}$. Orta çaplı damar vaskülitinden şüpheleniliyorsa eksizyonel ve daha derin bir biyopsi alınmaIıdır. Orta çaplı damar vaskülitlerinde livedo retikülariste patolojik değişiklikler derinde olduğu için patoloğun derin ve seri kesitler alması gereklidir24. Deri biyopsisi 24-48 saatlik lezyondan alınmalıdır, 48 saatten sonra infiltrattaki lenfositlerin oranı belirgin olarak artacağından spesifik tanı mümkün olmaz. Histolojik olarak sadece tromboz ya da perivasküler lenfositik infiltrat içeren biyopsiler klinik aksini düşündürüyorsa tekrarlanmalıdır ${ }^{21}$.

Direkt immünfloresanın kütanöz vaskülitlerin tanısında rutin kullanımı tartışmalıdır ${ }^{24}$. Direkt immünfloresandan sağlıklı sonuç alınabilmesi için erken lezyonlardan örnek alınmalıdır. 72 saatten büyük lezyonlarda direkt immünfloresanda immünglobulin tespit etmek zordur. Vasküler paternde $\operatorname{lgA}$ birikimi HSP veya IgA paraproteinemiyi düşündürür. Küçük damar kütanöz vaskülitlerinde direkt immünfloresanda damar duvarlarında granüler paternde C3-lgG, IgM ve/veya IgA

Tablo 4. Tutulan damar çapına göre vaskülitlere eşlik eden bulgular ${ }^{12,14}$

\begin{tabular}{|l|c|c|}
\hline Küçük & Orta & Büyük \\
\hline Purpura & Subkutan nodüller & Ekstremitede klodikasyo \\
\hline Ürtiker & Ülserler & Nabıtrik damar basıncı \\
\hline Vezikülöbüllöz lezyonlar & Livedeo retikülaris \\
\hline Splinter hemorajiler & Pitted palmar veya dijital skarlar & Aort diletasyonu \\
\hline Sklerit, episklerit, üveit & Dijital gangren & Üfürüm \\
\hline Glomerülonefrit & Mononöritis & - \\
\hline Gastrik kolik & Anevrizma & - \\
\hline Pulmoner hemoraji & Infarktlar & - \\
& Renal arter hipertansiyonu & - \\
\hline
\end{tabular}


( $\mathrm{G}>\mathrm{M}>\mathrm{A})$ birikimi görülmektedir ${ }^{2}$. Damarda veya çevresinde lgG, IgM ve/veya C3 varsa immünkompleks ilişkili tablolar: kriyoglobulinemik vaskülit, konnektif doku hastalığı vasküliti ve kütanöz lökositoklastik vaskülit düşünülür. Bazal membran zonda immünreaktanların olması lupus vaskülitini akla getirmelidir. Hipokomplementemik ürtikeryal vaskülit sendromunda da eşlik eden konnektif doku hastalığı varsa bazal membran zonda immünreaktan olabilir. Kriyoglobulinemik vaskülitlerde kan damarlarında lgM birikimi görülebi$\operatorname{lir}^{12}$. Kompleman veya immün kompleks birikimi yoksa veya az miktardaysa ANCA ilişkili vaskülitler düşünülmelidir². Vaskülit nedeniyle değerlendirilen hastalarda şüphelenilen vaskülite ve bu vaskülitin etkileyeceği organ sistemlerine uygun tanısal testler yapılmalı, 2,24 organ sistemlerinin etkilenme durumunu değerlendirmek için bazı laboratuar testleri her vaskülit epizodunda tekrar edilmelidir. Vaskülitle ilişkili hastalıklar için yapılan testler (HCV/HBV serolojisi) ilk tanı esnasında yapılır ve yalnızca yeni bilgi elde edilirse tekrarlanır².

Başlangıç aşamasında istenilecek tetkikler Tablo 5'de gösterilmiştir. Ateş, üfürüm, periferik yaymada bozukluk, sitopeni, HIV için risk faktörleri, şiddetli vaskülit sendromu varsa kan kültürü, ekokardiyografi, kan smir morfolojik çalışması, HIV serolojisi, visseral anjiyografi, kas biyopsisi veya etkilenen dokuların biyopsisi gibi ileri tetkikler planlanmalıdır $\mathbf{r}^{2,5,24}$.

ANCA pozitif vaskülitlerde basit tanısal yaklaşımda üç basamak vardır. İmmüfloresanda damarlarda ve çevresinde kompleman ve immünkompleks birikimi yoksa yani pauciimmün bir vaskülit söz konusu ise hasta MPA kabul edilir. Eğer akciğerde granülomatöz inflamatuar infiltrat varsa hasta WG'dir. Bunlara ek olarak eozinofil ve astım da varsa hasta CSS açısından değerlendirilmelidir. ANCA pozitif vaskülitlerde bu tür algoritmik yaklaşım her üç hastalıkta da agresif tedavi önerildiği için tedavinin gecikmesini önleyebilir.5 ANCA'nın indirekt immünfloresan ve myeloperoksidaz veya proteinaz 3 için antijen spesifik (ELISA) testlerle çalışılması otoantikorun spesifitesi ve sensitivitesini arttırdığından tablonun diğer ANCA pozitif hastalıklardan ayrımına yardımcı olur $^{4,14}$. Pulmoner hemoraji, uzun süreli otit veya sinüzit, retroorbital kitle veya sistemik bulgularla giden vaskülitlerde ANCA mutlaka bakılmalıdır.

Tablo 5. Vaskülitli hastalarda önerilen laboratuar tetkikleri

- Tam kan sayımı

- Tam idrar tetkiki

- Eritrosit sedimentasyon hızı

- Biyokimyasal panel

- Kan kreatinini ve kan üre azotu

- Gaytada gizli kan

- ANA, ANCA

- Romatoid faktör

- Kriyoglobulinler

- $\mathrm{C} 3, \mathrm{C} 4, \mathrm{CH} 50$ düzeyleri

- HBV, HCV serolojisi

- Akciğer grafisi

- İmmünglobulinler (IgG,A,M)

\section{Kaynaklar}

1. Barnhill RL, Nousari $\mathrm{CH}, \mathrm{Xu} X$, Barksdale SK: Vascular diseases. Lever's histopathology of the skin. Eds: Elder DE Elenitsas R, Johnson BL, Murphy GF, Xu X. Wolters Kluwer/ Lippincott Williams-Wilkins London, Philadelphia 2009;205-324.

2. Chung L, Kea B, Fiorentino DF: Cutaneous vasculitis. Dermatology. Eds. Bolognia JL, Jorizzo JL, Rapini RP. Spain, Elsevier, 2008;347-67.

3. Jennette JC, Falk RJ, Andrassy K, Bacon PA, Churg J, Gross WL, et al: Nomenclature of systemic vasculitides: proposal of an international consensus conference. Arthritis Rheum 1994:37:187-92.

4. Jennette JC, Falk RJ: Necrotizing Arteritis and Small Vessel Vasculitis. The Autoimmune Diseases Eds. Rose N, Mackay I. Academic Press 2006;899-920.

5. Fiorentino DF: Cutaneous vasculitis. J Am Acad Dermatol 2003;48:311-40

6. Jennette JC, Falk RJ: Small-vessel vasculitis. N Engl J Med 1997;337:1512-23.

7. Zeek PM: Periarteritis nodosa: A critical review. Am J Clin Pathol 1952:22:777-90.

8. Crissey JT: Parish LC. Vasculitis: the historical development of the concept. Clin Dermatol 1999:17:493-7.

9. Hunder GG, Arend WP, Bloch DA et al: The American College of Rheumatology 1990 criteria for the classification of vasculitis: introduction. Arthritis Rheum 1990:33:1065-7.

10. Soter NA, Diaz-perez JL: Cutaneous necrotizing venulitis. Fitzpatrick's Dermatology in General Medicine. Eds: Wolff K, Goldsmith LA, Katz SI, Gilchrest BA, Paller SA, Leffell DJ. McGraw-Hill Companies 2008; 1599-606.

11. Swerlick RA, Lawley TJ: Hypersensitivity vasculitis--not always benign? Lancet 1997;350:306-7.

12. Chen KR, Carlson JA: Clinical approach to cutaneous vasculitis. Am J Clin Dermatol 2008:9:71-92.

13. Khasnis A, Langford CA. Update on vasculitis. J Allergy Clin Immunol 2009;123:1226-36.

14. Carlson JA, Cavaliere LF, Grant-Kels JM: Cutaneous vasculitis: diagnosis and management. Clin Dermatol 2006;24:414-29.

15. Patel MJ, Jorizzo Jl: The Skin in Systemic Autoimmune Diseases: Cutaneous Small Vessel Vasculitis including Urticarial vasculitis. Handbook of Systemic Autoimmune Diseases. Ed. Sarzi-Puttini P, Doria A, Girolomoni G, Kuhn A, Asherson RA. Elsevier 2006;235-47.

16. Hautmann G, Campanile G, Lotti TM: The many faces of cutaneous vasculitis. Clin Dermatol 1999:17:515-31.

17. Katsambas A, Riga P: Purpura and vasculitis: unapproved treatments. Clin Dermatol 2002;20:626-33.

18. Ozen S, Pistorio A, lusan SM, Bakkaloglu A, Herlin T, Brik R: Paediatric Rheumatology International Trials Organisation (PRINTO). EULAR/PRINTO/PRES criteria for Henoch-Schönlein purpura, childhood polyarteritis nodosa, childhood Wegener granulomatosis and childhood Takayasu arteritis: Ankara 2008. Part II: Final classification criteria. Ann Rheum Dis 2010;69:798-806

19. Davies DJ: Small vessel vasculitis. Cardiovasc Pathol $2005 ; 14: 335-46$.

20. Langford CA. Vasculitis. J Allergy Clin Immunol 2010;125:216-25.

21. Grzeszkiewicz TM, Fiorentino DF: Update on cutaneous vasculitis. Semin Cutan Med Surg 2006;25:221-5.

22. Vena GA, Cassano N: Immunosuppressive therapy in cutaneous vasculitis. Clin Dermatol 1999;17:633-40.

23. Kausar S, Yalamanchili A: Management of haemorrhagic bullous lesions in Henoch-Schonlein purpura: is there any consensus? J Dermatolog Treat 2009;20:88-90.

24. Callen JP: A clinical approach to the vasculitis patient in the dermatologic office. Clin Dermatol 1999;17:549-53.

25. Mat C, Yurdakul S, Tüzüner N, Tüzün Y: Small vessel vasculitis and vasculitis confined to skin. Baillieres Clin Rheumatol 1997:11:237-57.

26. High WA, Hoang MP, Stevens K, Cockerell CJ: Late-stage nodular erythema elevatum diutinum. J Am Acad Dermatol 2003;49:764-7.

27. Gibson LE, el-Azhary RA: Erythema elevatum diutinum. Clin Dermatol 2000;18:295-9.

28. Wolf R, Tüzün $B$, Tüzün Y: Dapsone: unapproved uses or indications. Clin Dermatol 2000;18:37-53. 